\title{
Confracting for computer services in libraries
}

\author{
By Stuart Kohler
}

\section{Issues you need to consider when outsourcing}

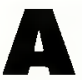
$s$ the use of computerized systems becomes more and more common in libraries of all sizes, so has the use of outside vendors, contractors, and consultants to install, implement, and maintain these systems. Acquiring systems, services, and applications may of ten be undertaken more cost-effectively by arranging for them with nonlibrary personnel, but once the decision to outsource is made, there are many issues that must be carefully considered. The recommendations presented here are general in nature and should not be taken to substitute for competent legal advice when drafting contractual documents.

\section{Introduction}

Libraries are no longer strictly the province of rows of card catalog drawers and shelves of books and periodicals. The long-standing icon of libraries, the catalog card with spindle hole, has given way to its electronic descendants, although not always without protest.'

Advances in information technology have definitively made way into the workl of business and publishing, but the impact on libraries has also been significant. Librarians see their role expanding from custodians of warehoused information to gatekeepers of electronic archives, often remote, of immense breadth and depth. ${ }^{2}$ As sophisticated applications of information technology continue to evolve for libraries, opting to obtain some of these resources from outsicle the library become appropriate alternatives.
Making the decision to outsource depends on many factors and is beyond the scope of this paper. The reader interested in this aspect of the outsourcing process is referred to several helpful publications in the literature. ${ }^{3-5}$ The focus in the present set of observations begins once the decision to outsource has been carefully weighed and identified as the course of action.

\section{Types of computer services}

The range of possible types of services runs from a contract for a specific piece of custom software to a comprehensive contract for the provision of complete librarywide computer services. While there may be some overlap in the following list, five general categories of outside assistance in automated systems may be identified:

1. Small, custom software applications (e.g., library kiosks, pieces of computer-assisted instruction, specific database applications for newsletter or mailing list purposes, etc.)

2. Services, such as short-term onsite training sessions for library staff, long-term agreements for user or network support, subscriptions to remote databases of periodicals or other content-specific resources, etc. Network services might also include the installation and maintenance of a local area network, including the required hardware and software, servers and workstations.

3. Purchase or lease of specific automated library modules, such as an online public-access catalog or an automated circulation system, usually to run on a personal computer.

4. Purchase or lease of an integrated library system which includes an OPAC and 
systems for circulations, serials, acquisitions, and other areas of library administration, usually to run on a mini or mainframe computer.

5. Comprehensive contracts for total library-wide automation, training, maintenance, upgrade, and support for all related computer systems.

\section{Issues to consider}

Potential problem areas may be divided into nine general categories:

1. Clear statement of need/clarity of contract. Not only should the statement of need explain specifically what is required, there should also be a brief summary of how the new system will improve efficiency, service, reduce costs, or other justification for undertaking the project. Build this specificity into the contract with the provider, as lack of clarity is a frequent cause of outsourcing problems. ${ }^{6}$

2. Evaluate contractors/vendors. If the project is large enough, it may be appropriate to call for bids. The library is paying for expertise but also experience. Therefore the library should ask questions such as: Has the contractor done similar work elsewhere? Are references available? If it is a new area for the contractor, will the fees reflect his or her learning curve?

3. Compatibility with existing systems, hardware, and/or software. Diversifying computing platforms (i.e., Windows or Macintosh or both?) may enfranchise new sectors of the library's community, but it also adds increased levels of complexity for maintenance, troubleshooting, and perhaps future expansion of related systems.

4. In-house maintenance requirements/ training of staff to operate new system. Who trains staff and will the original trainees be able to train new staff hired later? Will the system be a self-contained, dedicated-use system (stand-alone), which would be easier for staff to learn and use or will it be accomplished by adding on to an existing system? The latter may force staff to learn more about the general operation of the existing system than a dedicated-use application would. Training should also be included on backing up current data and archiving procedures for old data.

5. Scope of contract. Once the contract is turned over to library, is there any long-term responsibility by contractor if bugs are discovered or changes are desired? Who owns custom-written software? (See notes 7 and 8 for more information on copyright issues such as title and work for hire.) If the library does not obtain title to software, the consultant may realize additional profit by selling the same work again to another library, albeit with some modification. If so, the fee schedule should reflect the true value of what is being created and its true ownership. When contracting for full-text periodical databases, are there copyright restrictions?

6. Billing and completion arrangements. Will there be a single, flat fee for the completed/delivered product or an hourly fee for its creation? For hardware or systems maintenance contracts, will service calls be billed on an hourly basis or does the contract fee cover all necessary service requests? What is the time frame for delivery of completed work or for completion of repairs? The latter may be articulated in terms of performance measurements, such as performance goals and performance minimums.

7. Remedies for unacceptable work. Unfortunately, an unscrupulous entrepreneur may attempt to maximize profits by declining to deliver exactly what was promised in absence of specific remedies specified in writing.

\section{Likelihood of long-term accessibility} to information such as full-text periodical databases (especially important if considering cancellation of periodical subscriptions) or longterm usefulness of the software application under consideration.

9. Acceptance testing. Absolutely crucial and should inclucle a reasonable testing period-not simply a demo by the consultant at turnover.

\section{Example}

As an example of the process at a conceptual level, we will consider the development of a custom piece of software to maintain the membership records of a Friends of the Library organization, following the nine issues outlined above. Although the process becomes more complex for larger projects, the procedure will remain the same in principle.

The first step is to clearly state the goals, functionality, and features of the Friends software. This particular project would have as its goal the creation of software to collect, maintain, and extract information about the Friends membership including the elements of name, address, membership type, renewal date, and a miscellaneous note section. In terms of functionality and features, the system should be easy 
to use, must be able to produce (print on either paper or label stock) mailing lists (by zip code as well as last name) and renewal lists. In addition, the system must include a mail merge function able to produce customized correspondence to the membership.

Once this information is presented to the consultant, the next step is to establish an approximate time for completion of the project and identify if new or existing hardware (computer or printer) or new software (upgrade to current database application) will be required. If the latter is true, who is responsible for making the required purchases? Establish also who enters sample data for testing purposes and the complete data for the full system. If data are to be supplied by the library, what is the required data format? Clarify title to the resulting software and also clarify how much training of staff will be included by the consultant.

Finally, an overall fee for the project or an hourly rate should be agreed upon. If an hourly rate is selected, it may be useful to establish a maximum total charge to prevent the project from taking on a life of its own. As a precaution, discussion at this point should include remedies for undelivered or unacceptable work.

The next step is when the consultant returns with a demonstration version of the software, with evaluation done using sample data. At this point, change orders may be necessary. Requesting changes in the way the software operates or the pieces of information included is often a fact of life in software development. It is not necessarily evidence of poor planning or mistakes. Systems seem to have a natural "gestation" period, but it is essential to minimize the number of change orders and the magnitude of the changes requested. Each change from the original contract usually constitutes additional charges.

Acceptance testing with live data is usually the conclusion of the project, save for paying the consultant. At this point, the software would be "turned over" to the library and future responsibility for the consultant would likely occur only if bugs (such as dues payment miscalculations) show up after the acceptance testing is completed and the project accepted.

\section{Conclusion}

Effective management for incorporating information technology into the library setting maximizes both financial and personnel resources. The judicious use of automation expertise de- rived from consultants, contractors, or other vendors is a means to extend in-house technology capabilities and leverage improved services to the library's constituency.

\section{Notes}

1. Nicholson Baker, "Discards," New Yorker 70 (April 4, 1994): 64.

2. Paul Evan Peters, "Information Age Avatars," Library Journal 120 (March 15, 1995): $32-34$.

3. "Contract Management or Self-Operation: A Decision-Making Guide for Higher Education," CAUSE/EFFECT 16 (fall 1993): 6-10.

4. Robert J. Robinson, "Outsourcing's Potential in Higher Education," CAUSE/EFFECT 14 (summer 1991): 3, 39.

5. Contracting for Computing, Vol. 2. A Checklist of Terms and Clauses for Use in Contracting with Vendors for Software Packages and Custom Software (Princeton, N.J.: EDUCOM, 1975).

6. Ed Foster, "Outsource Sense," Infoworld 18 (September 9, 1996): 1, 77-78.

7. R. S. Talab, Copyright and Instructional Technologies. A Guide to Fair Use and Permissions Procedures, 2nd ed. (Washington, D.C.: Association for Educational Communications and Technology, 1977), 16. (A specific description of the term work for hire as related to the Copyright Act.)

8. Contracting for Computing, 106, 142-44. (Includes examples of contract clauses relating to the issue of title.)

\section{Feature your collection on the cover of C\&RL News}

CERL News wants to feature aesthetically pleasing photos of items from library collections on its covers. If you have material in your library's collections that you think would make an attractive CERL Nerus cover, please send us a photograph or a color photocopy and a brief description of the item and the collection. Photos may be either color or black-and-white and should be $5^{\prime \prime} \times 7^{\prime \prime}$ or $8^{\prime \prime} \times 10^{\prime \prime}$. Illustrations with a vertical orientation work best. Send to: CERL News Covers, 50 E. Huron St., Chicago, IL 60611. For more information contact Mary Ellen Davis at medavis@ala.org. 




